\title{
The Toxic Effects of Commonly Used Antibiotics in Turkey on Aquatic Organisms
}

\author{
V. Zülal SÖNMEZ $Z^{1,2 *} \quad$ Nüket SIVR $\dot{I}^{1}$ \\ ${ }^{I}$ Department of Environmental Engineering, İstanbul University-Cerrahpasa, 34320, Istanbul, Turkey. \\ ${ }^{2}$ Department of Environmental Engineering, Duzce University, 81620, Duzce, Turkey.
}

How to cite: Sönmez, V.Z. \& Sivri, N. (2020). The Toxic Effects of Commonly Used Antibiotics in Turkey on Aquatic Organisms. J. Anatolian Env. and Anim. Sciences, 5(2), 154-160.

Atıf yapmak için: Sönmez, V.Z. \& Sivri, N. (2020). Türkiye'de Yaygın Olarak Kullanılan Antibiyotiklerin Sucul Organizmalar Üzerindeki Toksik Etkileri. Anadolu Çev. ve Hay. Dergisi, 5(2), 154-160

\section{*Corresponding author's:} V. Zülal SÖNMEZ

Department of Environmental Engineering, İstanbul University-Cerrahpasa, 34320 , Istanbul, Turkey \: zulal.kiremitci@istanbul.edu.tr Mobile telephone : +90 (530) 1538999 Fax $\quad:+90(212) 4737180$
Abstract: Antibiotic pollution has the potential to directly affect the health of people, animals and the ecosystem. The presence of antibiotics in the environment can impede the structure of microbial community, having both acute and chronic effects on microbial and planktonic communities. In Turkey, the three most prevalent antibiotics detected in aquatic environment are Amoxicillin, Tetracycline and Nitrofurantoin, but there is almost no information on their toxicity on natural microbial communities. Particularly, there is no data available for marine microorganisms. While the amount of toxicity levels for humans is well known, there is less knowledge about toxic concentration in wildlife, especially smaller and more vulnerable organisms. Consequently, the purpose of this current study is to evaluate the acute toxicity of Amoxicillin, Tetracycline and Nitrofurantoin to the natural water ecosystem, a complex ecological group comprising a variety of bacterial and planktonic species. It is seen that antibiotics are practically non-toxic (>100 mg/L) in the classification of acute toxicity according to Daphnia magna. It is not possible to mention about toxicity in this case, but when considering the toxicity of antibiotics among themselves, the ranking is like Tetracycline > Nitrofurantoin > Amoxicillin. The same toxicity ranking is encountered in the acute toxicity test made with Vibrio fischeri. However, in the acute toxicity test made with Vibrio fischeri, the results are toxic for Tetracycline $(2.53 \mathrm{mg} / \mathrm{L})$, Nitrofurantoin $(15.67 \mathrm{mg} / \mathrm{L})$ and Amoxicillin $(56.23 \mathrm{mg} / \mathrm{L})$. While antibiotics have an acute effect on bacterial structures, they tend to have a chronic effect and bioaccumulation properties on Daphnids.

\section{Türkiye'de Yaygın Olarak Kullanılan Antibiyotiklerin Sucul Organizmalar Üzerindeki Toksik Etkileri}

*Sorumlu yazar:

İstanbul Üniversitesi-Cerrahpașa, Cevre

Mühendisliği Bölümü, 34320, İstanbul,

Türkiye

\: zulal.kiremitci@istanbul.edu.tr

Cep telefonu : +90 (530) 1538999

Faks $\quad:+90(212) 4737180$
Öz: Antibiyotik kirliliği, insan, hayvan ve ekosistem sağlığını doğrudan etkileme potansiyeline sahiptir. Çevrede antibiyotiklerin varlığı, mikrobiyal topluluk yapısını engelleyebilir ve mikrobiyal ve planktonik topluluklar üzerinde hem akut hem de kronik etkileri olabilir. Türkiye'de su ortamında tespit edilen en yaygın üç antibiyotik Amoksisilin, Tetrasiklin ve Nitrofurantoin'in, doğal mikrobiyal topluluklar üzerindeki toksisiteleri hakkında neredeyse hiçbir bilgi yoktur. Özellikle, deniz mikroorganizmaları için hiçbir veri yoktur. İnsanlar için toksisite seviyeleri oldukça iyi bilinse de, doğal hayatta özellikle daha küçük ve daha duyarlı organizmalardaki toksik konsantrasyon hakkında daha az bilgi vardır. Bu nedenle, bu çalışmanın amacı Amoksisilin, Tetrasiklin ve Nitrofurantoin'in çeşitli bakteriyel ve planktonik türleri içeren karmaşık bir ekolojik topluluk olan doğal su ekosistemi üzerindeki akut toksisitesini değerlendirmektir. Daphnia magna'ya göre akut toksisite sınıflandırmasında antibiyotiklerin pratik olarak toksik olmadığ 1 (>100 mg/L) görülmektedir. Bu durumda toksisiteden bahsetmek mümkün değildir, ancak kendi aralarında antibiyotiklerin toksisitesi göz önüne alındığında, sıralama Tetrasiklin> Nitrofurantoin> Amoksisilin şeklinde olmaktadır. Vibrio fischeri ile yapılan akut toksisite testinde aynı toksisite sıralamasına rastlanmaktadır. Bununla birlikte, Vibrio fischeri ile yapılan akut toksisite testinde, sonuçlar Tetrasiklin $(2.53 \mathrm{mg} / \mathrm{L})$, Nitrofurantoin $(15.67 \mathrm{mg} / \mathrm{L})$ ve Amoksisilin $(56.23 \mathrm{mg} / \mathrm{L})$ için toksik olmaktadır. Antibiyotikler, bakteriyel yapılar üzerinde akut bir etkiye sahipken, Daphnidler üzerinde kronik bir etki ve biyoakümülasyon özelliklerine sahip olma eğilimindedir.

Anahtar kelimeler: Antibiyotikler, akut toksisite, biyodeneyler, Daphnia magna, Vibrio fischeri, Türkiye. 


\section{INTRODUCTION}

Antibiotics are often found in the aquatic environment, because of their utilization in human and veterinary medicine. Information relating their exposure, fate and ecotoxicology has been reviewed by Kümmerer, (2009a, 2009b) and Santos et al., (2010) (Johansson et al., 2014). Up to $90 \%$ of antibiotics applied to the organism are excreted from the body before being metabolised (Kemper, 2008; Topal et al., 2015) and discharged into sewage system (Diwan et al., 2018; Gomez-Olivan, 2016; Yasser \& Adli, 2015). The conventional wastewater treatment plants (WWTPs) are not fully effective at antibiotic elimination. Several antibiotics are partially removed between 20\% and 90\% (Ai \& Jiang, 2012; Liu et al., 2017; Watkinson, 2007) due to recalcitrant compounds (Chen \& Zhou, 2014). WWTPs are considered as the source of antibiotics and antibiotic resistance genes for surface waters (Diwan et al., 2018; Gomez-Olivan, 2016). For this reason, studies are carried out on the development of innovative technologies for antibiotic removal in WWTPs. However, these implementations are not covered sufficiently because of operating costs (Grenni et al., 2018).

Antibiotics occur in surface waters at very low concentrations (ng/L- $\mu \mathrm{g} / \mathrm{L})$ (Gomez-Olivan, 2016). It can be observed that there are differences regarding seasonal distribution of pharmaceutical products usage in Turkey. It is known that antibiotic concentrations in wastewater are higher in winter with changes in annual consumption data (Grenni et al., 2018). For instance, in winter months at coastal area of Istanbul, the concentration of antibiotic agent sulfamethoxazole varied between 6,7 and 14,0 ng/L. The availability of antibiotics in the aquatic environment is depending on not only continuity of their discharges but also their permanence in the aquatic environments. For instance, while Penicillins can easily deteriorate, Ciprofloxacin and Tetracyclines are far more stable (Grenni et al., 2018). Even this low concentration can cause negative effect on the survival, growth and body weight of the aquatic organisms (Ahmed et al., 2015; Ji et al., 2012; Lai et al., 2009; Wollenberger et al., 2000). Some antibiotics can cause both acute and chronic toxicity, as well as a variety of negative effects including disruption of aquatic photosynthetic organisms, impacts on indigenous microbial groups, and damage to antibiotic resistance genes in microorganisms (Aristilde et al., 2010; Hong et al., 2013; Liu et al., 2017, Akkan \& Topkaraoğlu, 2019; Sezener et al., 2019). For that reason, the presence of antibiotics can affect water quality of surface water, and in the long run cause negative impact on coastal areas and naturally the biodiversity (URL 1).

It is known that over 250 different antibiotics are being used in human and veterinary medicine (Ahmed et al., 2015; Kümmerer \& Henninger, 2003). Antibiotics have been used to treat infection-related diseases therapeutically, and to protect their health for years (Ahmed et al., 2015). Each antibiotic is a synthetic structure with a complex formula containing the properties of its own class. For instance, Amoxicillin is a semisynthetic penicillin and a medicine which is an analogue for ampicillin (Gomez-Olivan, 2016). It is one of the antibiotics used in treatment of infections of ear, respiratory tract, sinus, skin and urinary system caused by bacteria. It is included in Essential Medicine List of World Health Organization, and it is one of the most prescribed antibiotics for children (URL 2). In addition, according to the data published by the Republic of Turkey Ministry of Health, prescribed antibiotics is over $30 \%$ across Turkey in 2015 (URL 3). In the light of this information, the most prescribed antibiotic is the Amoxicillin-derived antibiotics. Tetracycline is an antibiotic which is used to treat and prevent the infectious diseases. However, the explanation for this intensive production is both its low cost and its use as a food additive to increase the growth rate of healthy animals (Daghrir \& Drogui, 2013; Martins et al., 2015). Nitrofurantoin is another antibiotic and commonly used in the treatment of urinary tract infections. It is active on many gram-positive and gram-negative bacteria, especially Escherichia coli, Staphylococcus aureus and enterococci strains (Eldem \& Hincal, 1987).

Amoxicillin, Tetracycline, Nitrofurantoin are amongst the most used antibiotic classes and they are often found in aquatic environments in Turkey. However, all the classes are mainly observed in freshwater environments, with simplest a very few researches published on their occurrence inside the marine environment in Turkey. Similarly, it is essentially absent the statistics on the toxicity of these three antimicrobial classes to marine microorganisms which are possibly the most vulnerable group of marine organisms.

In literature, different toxicity test organisms have been used to determine the acute and chronic toxicity of antibiotics (Halling-Sorensen, 2000; Jung et al., 2008; Robinson et al., 2005; Wang et al., 2008; Wollenberger et al., 2000). Daphnia magna, which is a zooplankton generally observed in freshwater lakes and ponds, is one of the most frequently used organisms in ecotoxicity tests (Celebi \& Sponza, 2009; Zhu et al., 2009). In Ecological Risk Assessments of Antibiotics, toxicity tests are used that target bacteria such as Vibrio fischeri with OECD and ISO methods (Backhaus et al., 2000; Backhaus \& Grimme, 1999; Celebi \& Sponza, 2008; Grenni et al., 2018; Tongur et al., 2019; Y1ldırım, 2015).

Therefore, aim of this current study is to evaluate the acute toxicity of Amoxicillin, Tetracycline and 
Nitrofurantoin on natural water ecosystem which is a diverse ecological population comprising a number of bacterial and planktonic species. Thus, the effect of antibiotics on organisms at two different trophic levels of the aquatic ecosystem was evaluated.

\section{MATERIAL AND METHOD}

The Selection and Preparation of Antibiotics: In this study, synthetic samples were prepared with medicines containing the active ingredients of Amoxicillin, Tetracycline and Nitrofurantoin. With distilled water, stock solutions were prepared. Because the selected antibiotics have low water solubility, hydro alcoholic (< $1 \%$ ethanol) solution was used. According to standard international procedures, it is stated that hydro alcoholic solution is not toxic for test organisms in cases that ethanol concentration is not more than $1 \%$ (Y1ldirım, 2015). This ratio has been confirmed by preliminary experiments. When preparing stock solutions for each medicine, the medicine is dissolved with $<\% 1$ ethanol by volume and then completed with distilled water. Orbital shaker was used to provide homogeneous mixture (URL 4).

Daphnia magna Acute Immobilisation Test: The acute test was conducted as ISO 6341: Water Quality Determination of the Inhibition of the Mobility of Daphnia magna, Straus (Cladocera, Crustacea). Daphnids (especially Daphnia magna) which are younger than 24 hours were exposed to sample concentrations. The vessels were filled with suitable amounts of dilution water and samples. Then, Daphnids were placed into test vessels. at least $2 \mathrm{ml}$ of test solution needed for each test organism, so the volume of $20 \mathrm{ml}$ test media for 10 daphnids was examined. During the test, the organisms were not fed and there was no aeration. At the same time, the temperature was adjusted to $22^{\circ} \mathrm{C}$. Under the same conditions, the controls were carried out. After 24 and 48 hours, both immobility and unnatural behaviours were reported. At $24^{\text {th }}$ and $48^{\text {th }}$ hours, each vessel was inspected for immobilised daphnids. The daphnids were considered as immobile unless they were able to swim inside the vessel, all these were recorded. In order to calculate the average effective concentration $\left(\mathrm{EC}_{50}\right)$ value, immobilized/dead daphnids corresponding to each concentration will be used within the $95 \%$ confidence interval through Probit Analysis, suggestion of EPA (URL 5; EPA, 1991). Probit analysis is a type of regression used to analyze binomial response variables. It transforms the sigmoid doseresponse curve to a straight line that can then be analyzed by regression either through least squares or maximum likelihood.

Bacterial Bioluminescence Bioassay (Acute Toxicity Test): Microtox ${ }^{\circledR}$ Acute Toxicity Test is predicated on luminescence inhibition of the marine gramnegative bacteria. As test organism, Lyophilized Vibrio fischeri (NRRLB-11177) was selected and tested in standard protocol for producers (Microtox ${ }^{\circledR}$ Manual, 1992). Bacterial suspension was added to the sample osmotically arranged with $2 \% \mathrm{NaCl}$ and to the sample dilutions. Photometry was performed regularly after the bacteria had been exposed to the sample. Acute toxicity tests were performed via Microtox Model 500 Analyser. The manufacturer suggested the Basic Test (45\%) for samples of uncertain toxicity and wastewater (Sönmez \& Sivri, 2016; Sönmez \& Sivri, 2020). For implementation of this test, the exposure time was selected as 15 minutes and $\mathrm{EC}_{50}$ values were found.

\section{RESULTS AND DISCUSSIONS}

In this study, two main topics were focused. The first one was to evaluate the effects of acute toxicity of antibiotics on natural water ecosystem with bacterial and planktonic species. The other aim was to compare and interpret the acute toxicity results found. For acute toxicity test with Daphnia magna, preliminary tests were made, and the concentration range was chosen that daphnids could respond as dead/immobile against the antibiotics. Accordingly, all antibiotics were studied at the concentration of $2000 \mathrm{mg} / \mathrm{L}$ for Daphnia magna acute test. The result values of Daphnia magna's 24-hour exposure to three different antibiotics (Amoxicillin, Tetracycline and Nitrofurantoin) as $\mathrm{EC}_{10}, \mathrm{EC}_{20}, \mathrm{EC}_{50}$ and $\mathrm{EC}_{90}$ are given in Figure 1. These results were found with the mean values obtained as a number of repetitions $(n=14)$. Especially when examining the $\mathrm{EC}_{50}$ results, it is seen that its value is over $1000 \mathrm{mg} / \mathrm{L}$ for all antibiotics. Accordingly, it can be stated that 24-hour exposure of antibiotics on Daphnia magna has non-toxic property when they are subjected to the classification of acute toxicity.

It is seen that low concentrations of general antibiotics such as Streptomycin and Erythromycin affect the survival and behaviour of organisms in primary consumer trophic class such as Daphnia magna (Flaherty \& Dodson, 2005) and Artemia sp. (Migliore et al., 1997). In further studies, it is emphasized the effect of antibiotic toxicity after exposure of organisms to the UV radiation in natural environment. For this reason, it becomes difficult to evaluate the relationship between laboratory studies and antibiotic toxicity in natural environments (Kraemer et al., 2019).

The result values of Daphnia magna's 48-hour exposure to three different antibiotics (Amoxicillin, Tetracycline and Nitrofurantoin) as $\mathrm{EC}_{10}, \mathrm{EC}_{20}, \mathrm{EC}_{50}$ and $\mathrm{EC}_{90}$ are given in Figure 2. Unlike the 24-hour results, values of this exposure are below $1000 \mathrm{mg} / \mathrm{L}$. Accordingly, $\mathrm{EC}_{50}$ values of the exposure result of Amoxicillin, 
Tetracycline and Nitrofurantoin with Daphnia magna are respectively $627,198,878$ and $432 \mathrm{mg} / \mathrm{L}$. When examining the acute toxicity results according to the exposure times, it can be said that 48 -hour exposure is more sensitive, but it is stated as practically non-toxic $(>100 \mathrm{mg} / \mathrm{L})$ in classification of acute toxicity. In this case, it is not possible to mention about toxicity. Yet still, it may provide insight into their effect levels, because antibiotics have chronic effects on daphnids-like organisms and cause bioaccumulation in high-level organisms. Considering their toxicity among themselves, the ranking can be expressed as Tetracycline > Nitrofurantoin > Amoxicillin. It can be thought that this difference is due to its chemical structure, like Grenni et al., (2018) stated in their studies, which is each of them has a more persistent structure compared to the other.

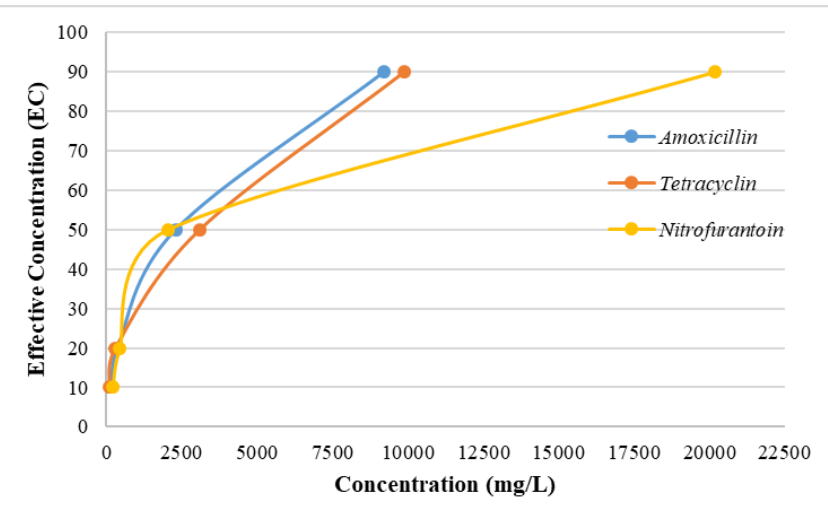

Figure 1: Results of acute toxicity test with Daphnia magna (24 hours).

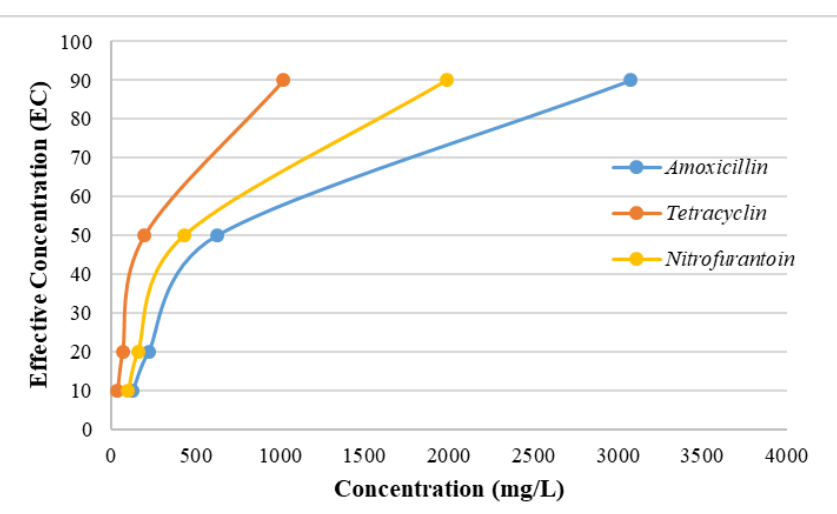

Figure 2: Results of acute toxicity test with Daphnia magna (48hour).

Preliminary tests $(\mathrm{n}=11)$ were carried out to conduct the acute toxicity test with Vibrio fischeri. High concentrations of daphnids were studied but it was not possible to obtain a numerical value as all bacteria were inhibited. For this reason, antibiotic tests were prepared in the minimum concentration range that we can get a result from test (that bacteria can emit light). Accordingly, concentrations of Amoxicillin $4000 \mathrm{mg} / \mathrm{L}$, Tetracycline $125 \mathrm{mg} / \mathrm{L}$ and Nitrofurantoin $250 \mathrm{mg} / \mathrm{L}$ were selected. $15^{\text {th }}$ minute results of acute toxicity test with Vibrio fischeri are given in Figure 3. All values obtained are below $100 \mathrm{mg} / \mathrm{L}$ and show toxic properties. These results were found with the mean values obtained as a number of repetitions $(\mathrm{n}=14)$.

Tetracycline, which was studied at the lowest concentration, has the highest toxicity $(2.53 \mathrm{mg} / \mathrm{L})$ as it has the lowest value with $\mathrm{EC}_{50}$ Nitrofurantoin $(15.67 \mathrm{mg} / \mathrm{L})$ comes after Tetracycline in terms of toxicity. Both antibiotics are included in "extremely toxic" class. Amoxicillin has the lowest toxicity with an $\mathrm{EC}_{50}$ value of $56.23 \mathrm{mg} / \mathrm{L}$ and it is included in "toxic" class with this result.

It is obvious that the potential effects of the studied antibiotics on natural microbial communities involved in important ecosystem functions are harmful. Some antimicrobials are bactericide for one bacterial pathogen, while they are bacteriostatic for another. Selected bacteriostatic agents inhibit the growth of bacterial cells but do not kill them; but bactericidal agents kill the bacteria instantly. As a result, these categories are not absolute, because the lethal effect of each medicine varies according to the test method and the tested species. As a result of the study, it is seen that some microbial groups may be lost because of bactericidal and bacteriostatic effects of antibiotics at high concentrations in the environment. Many studies have shown that the presence of antibiotics cause a decrease in microbial biodiversity. It is seen that antibiotics, even those with broad-spectrum, have a selective effect on various microbial groups (Genni et al., 2018).

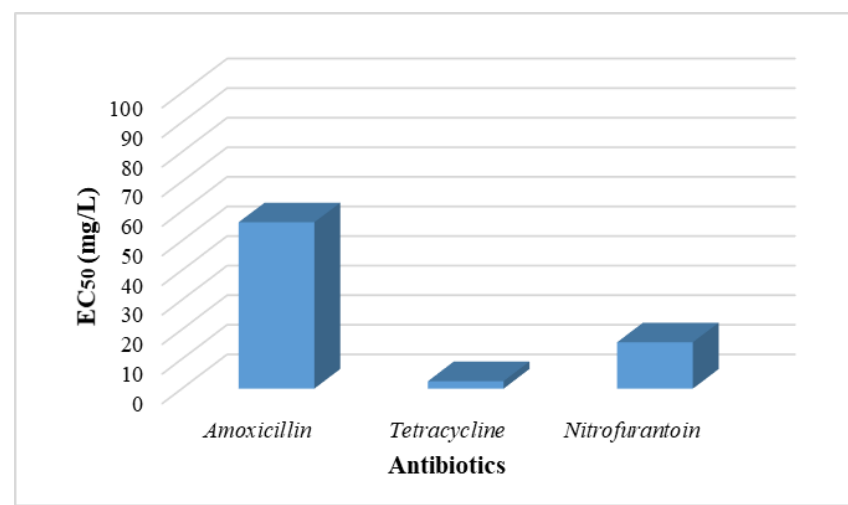

Figure 3: Results of acute toxicity test with Vibrio fischeri (15 minutes).

Comparing the results of acute toxicity tests with Daphnia magna and Vibrio fischeri, the studied antibiotics showed non-toxic properties on Daphnia magna, while they showed extremely toxic / toxic properties on Vibrio fischeri. It is seen that the studied Amoxicillin, Tetracycline and Nitrofurantoin are more sensitive and able to respond acutely on Vibrio fischeri. Another remarkable result is that the quantity of Daphnia magna's response to these antibiotics has parallels with Vibrio 
fischeri. Accordingly, the highest toxicity was found in Tetracycline and the lowest toxicity was found in Amoxicillin.

Tongur \& Yıldırım, (2015) have studied the toxicity of antibiotics used in human and animal medicine and they have found that Vibrio fischeri is more sensitive than Lepidium sativum. In studies to reveal the toxic effect in aquatic environments, $\mathrm{LC}_{50}$ value was found as 1000 $\mathrm{mg} / \mathrm{L}$ as a result of 96-hour-exposure to Amoxicillin on Oryzias latipes and it has not been identified as an important toxic substance in the literature (Gomez-Olivan, 2016). Nevertheless, Andreozzi et al., (2004) have detailed that Amoxicillin includes a high toxicity at 96 hours within the blue green algae $S$. leopoliensis $\left(\mathrm{EC}_{50}\right.$ value of 2.22 $\mu \mathrm{g} / \mathrm{L})$ in concentrations between of $50 \mathrm{ng} / \mathrm{L}$ and $50 \mathrm{mg} / \mathrm{L}$. Gomez-Olivan, (2016) explained that this difference in toxicity arose from organisms may be caused by trophic levels, even antibiotics at low concentrations may cause high toxicity in low structured organisms such as algae and bacteria. It is obvious that this effect, especially seen in single cells, will cause damage in aquatic environments.

It is found in studies that antibiotic pollution in aquatic environments reduces the microbial diversity of the ecosystem, including taxa responsible for carbon cycle and primary production. In addition to aquatic ecosystem, antibiotic-based pollution observed in soil changes the microbial community structure and leads to loss of biomass and reduce of microbial activity (nitrification, denitrification and respiration) (Kraemer et al., 2019). For this reason, as determined in this study, it can be stated that the toxic effects of antibiotics are seen more clearly in bacterial species due to the difference in trophic levels in organisms.

\section{CONCLUSION}

The presence of antibiotics in the environment can impede the structure of microbial community, having both acute and chronic effects on microbial communities. Antibiotics may have effects on change of phylogenetic structure, resistance expansion, and ecological function disturbance in the micro-ecosystem. Moreover, it has also been detected the effects on ecological functions, such as nitrogen transformation, methanogens, and sulphate reduction. A lot of studies have found changes in the structure of microbial population upon the introduction of antibiotics in soil and water environments. These study results include findings and comments supporting previous studies. As a result of the studies, it can be predicted that irreversible destructions will occur in both aquatic and terrestrial ecosystems.

As recommendations considered necessary because of these study results, the factors influencing antibiotic effects on microbial communities in soil and aquatic environments, including antibiotic concentration, exposure time and combination of effects of more than one antibiotic, should be examined in detail.

Furthermore, this study provides possible toxic effects of antibiotics in the natural environment. Nonetheless, it needs further study after the findings concerning the acute toxicity in order to provide a extensive risk assessment on the effects of anthropogenic antibiotic exposure in natural systems.

\section{CONFLICT OF INTEREST}

The authors declare that there is no conflict of interest.

\section{ACKNOWLEDGMENTS}

The authors especially thank Mrs. Nilay ELMACIOGLU, Mr. Vedat ELLIALTI and Mr. Görkem SANDIKCI for their assistance during field work and for excellent technical assistance.

This manuscript was presented with preliminary analysis results at the International Congress on Advances in Bioscience and Biotechnology (ICABB 2018), Podgorica, MONTENEGRO

\section{REFERENCES}

Ahmed, M.B., Zhou, J.L., Ngo, H.H. \& Guo, W. (2015). Adsorptive removal of antibiotics from water and wastewater: progress and challenges. Science of the Total Environment, 532, 112-126.

Ai, L. \& Jiang, J. (2012). Removal of methylene blue from aqueous solution with Self-Assembled Cylindrical Graphene-Carbon Nanotube Hybrid. Chemical Engineering Journal, 192, 156-163.

Akkan, T. \& Topkaraoğlu, T. (2019). Determination of Antibiotic Resistance Levels of Escherichia coli Isolates Obtained from Freshwater Sources: Batlama Creek, Gires. Journal of Anatolian Environmental and Animal Sciences, 4(3), 539544.

Aristilde, L., Marichal, C., Miéhé-Brendlé, J., Lanson, B. \& Charlet, L. (2010). Interactions of Oxytetracycline with a Smectite Clay: A spectroscopic study with molecular simulations. Environmental Science \& Technology, 44, 78397845.

Backhaus, T., Altenburger, R., Boedeker, W., Faust, M., Scholze, M. \& Grimme, L.H. (2000). Predictability of the toxicity of a multiple mixture of dissimilarly acting chemicals to Vibrio fischeri. Environmental Toxicology and Chemistry, 19(9), $2348-2356$ 
Çelebi, H. \& Sponza, D. (2008). Amoksisilinin Anaerobik Arıtılabilirliği. ITU dergisi/e $\mathrm{Su}$ Kirlenmesi Kontrolü, 18 (2-3), 41-50.

Celebi H. \& Sponza, D. (2009). Anaerobic treatment of antibiotics, toxicity removal and biogas production. 14th National Biomedical Engineering Meeting, Balcova, Izmir, 1-4.

Chen, K. \& Zhou, J. (2014). Occurrence and behavior of antibiotics in water and sediments from the Huangpu River, Shanghai, China. Chemosphere, 95, 604-612.

Daghrir, R. \& Drogui, P. (2013). Tetracycline antibiotics in the environment: A review. Environmental Chemistry Letters, 11(3), 209-227.

Diwan, V., Hanna, N., Purohit, M., Chandran, S., Riggi, E., Parashar, V., Tamhankar, A.J. \& Stalsby Lundborg, C. (2018). Seasonal variations in water-quality, antibiotic residues, resistant bacteria and antibiotic resistance genes of Escherichia coli isolates from water and sediments of the Kshipra River in Central India. International Journal of Environmental Research and Public Health, 15(1281), 1-16.

Gomez-Olivan, L.M. (2016). Amoxicillin in the Aquatic Environment, Its Fate and Environmental Risk. In: Marcelo L. Larramendy \& Sonia Soloneski (ed.), Environmental Health Risk - Hazardous Factors to Living Species, 248-267 p, IntechOpen. http://dx.doi.org/10.5772/62049

Eldem, T. \& Hincal, A.A. (1987). Nitrofurantoin. FABAD Journal of Pharmaceutical Sciences, 12, 170-178. (in Turkish).

EPA (1991). U.S Environmental Protection Agency, U.S. Army Corps of Engineers, Short Term Methods for Estimating The Chronic Toxicity of Effluents and Receiving Waters to Fresh Organisms, Washington.

Flaherty, C.M. \& Dodson, S.I. (2005). Effects of pharmaceuticals on Daphnia survival, growth, and reproduction. Chemosphere, 61, 200-207.

Grenni, P., Ancona, V. \& Caracciolo, A.B. (2018). Ecological effects of antibiotics on natural ecosystems: A review. Microchemical Journal, 136, 25-39.

Halling-Sørensen, B. (2000). Algal toxicity of antibacterial agents used in intensive farming. Chemosphere, 40(7), 731-739.

Hong, P., Al-Jassim, N., Ansari, M. \& Mackie, R. (2013). Environmental and public health implications of water reuse: Antibiotics, antibiotic resistant bacteria, and antibiotic resistance genes. Antibiotics, 2, 367-399.

ISO 6341:2012 Water Quality - Determination of the Inhibition of the Mobility of Daphnia magna Straus (Cladocera, Crustacea) https://www.iso.org/standard/54614.html

Ji, K., Kim, S., Han, S., Seo, J., Lee, S., Park, Y., Choi, K., Kho, Y.L., Kim, P.G. \& Park, J., (2012). Risk assessment of Chlortetracycline, Oxytetracycline, Sulfamethazine, Sulfathiazole, and Erythromycin in aquatic environment: Are the current environmental concentrations safe? Ecotoxicology, 21, 2031-2050.

Johansson, C.H., Janmar, L. \& Backhaus, T. (2014). Toxicity of Ciprofloxacin and Sulfamethoxazole to marine periphytic algae and bacteria. Aquatic toxicology, 156, 248-258.

Jung, J., Kim, Y., Kim, J., Jeong, D.H. \& Choi, K. (2008). Environmental levels of ultraviolet light potentiate the toxicity of Sulfonamide antibiotics in Daphnia magna. Ecotoxicology, 17(1), 37-45.

Kemper, N. (2008). Veterinary antibiotics in the aquatic and terrestrial environment. Ecological Indicators, 8, 1-13.

Kraemer, S.A., Ramachandran, A. \& Perron, G.G. (2019). Antibiotic pollution in the environment: From microbial ecology to public policy. Microorganisms, 7(6), 180.

Kümmerer, K. \& Henninger, A. (2003). Promoting resistance by the emission of antibiotics from hospitals and households into effluent. Clinical Microbiology and Infection, 9 (12), 1203-1214.

Kümmerer, K. (2009a). Antibiotics in the aquatic environment-A review-Part I. Chemosphere, 75(4), 417-34. DOI: 10.1016/j.chemosphere.2008.11.086

Kümmerer, K. (2009b). Antibiotics in the aquatic environment-A review-Part II. Chemosphere, 75(4), 435-41. DOI: 10.1016/j.chemosphere.2008.12.006

Lai, H.T., Hou, J.H., Su, C.I., Chen \& C.L. (2009). Effects of Chloramphenicol, Florfenicol, and Thiamphenicol on growth of algae Chlorella pyrenoidosa, Isochrysis galbana, and Tetraselmis chui. Ecotoxicology and Environmental Safety, 72 (2), 329-334.

Liu, M.K., Liu, Y.Y., Bao, D.D., Zhu, G., Yang, G.H., Geng, J.F. \& Li, H.T. (2017). Effective removal of Tetracycline antibiotics from water using hybrid carbon membranes. Scientific Reports, 7 (43717), 1-8.

Martins, A.C., Pezoti, O., Cazetta, A.L., Bedin, K.C., Yamazaki, D.A., Bandoch, G.F., Asefa, T., Visentainer, J.V. \& Almeida, V.C. (2015). Removal of Tetracycline by $\mathrm{NaOH}$-activated carbon produced from macadamia nut shells: Kinetic and equilibrium studies. Chemical Engineering Journal, 260, 291-299.

Microtox ${ }^{\circledR}$ Manual, (1992). A Toxicity Testing Handbook. Microbics Corporation, Carlsbad, CA, USA, $5 p$.

Migliore, L., Civitareale, C., Brambilla, G. \& Dojmi Di Delupis, G. (1997). Toxicity of several important agricultural antibiotics to Artemia. Water Research, 31, 1801-1806.

Robinson, A.A., Belden, J.B. \& Lydy, M.J. (2005). Toxicity of Fluoroquinolone antibiotics to aquatic organisms. Environmental Toxicology and Chemistry: An International Journal, 24(2), 423430.

Santos, L.H.M.L.M., Araújo, A.N., Fachini, A., Pena, A., Delerue-Matos, C. \& Montenegro, 
M.C.B.S.M. (2010). Ecotoxicological aspects related to the presence of pharmaceuticals in the aquatic environment. Journal of Hazardous Materials, 175(1-3), 45-95. DOI: 10.1016/j.jhazmat.2009.10.100.

Sezener, M.G., Findik, A., Erguden, V.E., Akgoz, S., Gulhan, T. \& Ciftci A. (2019). The determination of antibiotic resistances and some virulence genes of Staphylococcus aureus isolated from bovine mastitis. Journal of Anatolian Environmental and Animal Sciences, 4(2), 182187.

Sönmez, V.Z., \& Sivri, N. (2016). Interlaboratory precision of acute toxicity tests using reference toxicant formaldehyde. Journal of Anatolian Environmental and Animal Sciences, 1(3), 96-99.

Sönmez, V. Z., \& Sivri, N. (2020). Change of Acute Toxicity of Dyestuff Wastewaters. Polish Journal of Environmental Studies, 29(1), 491-498.

Tongur, S. \& Yildirim, R. (2015). Acute toxicity assessment of antibiotics in water by luminiscence bacteria and Lepidium sativum. Procedia Earth and Planetary Science, 15, 468-473.

Tongur, S., Yıldız, S. \& Yıldırım, R. (2019). Assessment of acute toxicity of some pharmaceuticals effects in aquatic environment by toxicity test methods. Süleyman Demirel University Journal of Natural and Applied Sciences, 23, Special Issue, 71-75.

Topal, M., Uslu G., Arslan Topal, E.I. \& Öbek, E. (2015). Antibiyotikler ve kullanım alanları. Erciyes Üniversitesi Fen Bilimleri Enstitüsü Fen Bilimleri Dergisi, 31(3), 121-127. (in Turkish).

URL 1. Study Report Daphnia magna, Acute lmmobilization Test Effect of Linevol on the immobilization of Daphnia magna in closed vessels, Test guideline: OECD 202, GLP-Code of Testing Facility: SDA-004/4-20. http://aciscience.com/docs/Linevol\%20Daphnia $\% 200 E C D 202$.pdf. (10 January 2020)

URL 2. Amoxicillin Wikipedia, http://www.wikizeroo.com/index.php?q=aHR0c HM6Ly9lbi53aWtpcGVkaWEub3JnL3dpa2kvQ W1veGljaWxsaW4 (26 January 2020).

URL 3. Bir Bakışta Ekotoksisite Testleri, ALS Environmental.

http://alsglobal.com.tr/website/var/assets/mediatr/pdf/ecotoxicity-tests-at-a-glance_2015_tur.pdf (in Turkish) (26 January 2020).

URL 4. Antibiotic Solubility Data Table, TOKU-E, https://www.toku-e.com/Antibiotic-Solubility-

Data-Table.aspx (26 January 2020).

URL 5. OECD Guideline for Testing of Chemicals, Daphnia sp., Acute Immobilisation Test. https://read.oecd-ilibrary.org/environment/testno-202-daphnia-sp-acute-immobilisationtest_9789264069947-en\#page1 (26 January 2020).

Wang, H.Z., Luo, Y., Xu, W.Q., Zhou, Q.X., Tang, B.H. \& Wang, Y.Y. (2008). Ecotoxic effects of Tetracycline and Chlortetracycline on aquatic organisms. Journal of Agro-Environment Science, 4, 048.

Watkinson, A.J., Murby, E.J. \& Costanzo, S.D. (2007). Removal of antibiotics in conventional and advanced wastewater treatment: Implications for environmental discharge and wastewater recycling. Water Research, 41(18), 4164-4176.

Wollenberger, L., Halling-Sørensen, B. \& Kusk, K.O. (2000). Acute and chronic toxicity of veterinary antibiotics to Daphnia magna. Chemosphere 40, 723-730.

Yasser, E.N. \& Adli, A. (2015). Toxicity of single and mixtures of antibiotics to cyanobacteria. Journal of Environmental \& Analytical Toxicology, 5(3), 1.

Yıldırım, R. (2015). Acute toxicity determination of antibiotics by toxicity test methods. Selçuk University, Science Institute Konya, Turkey, 91p.

Zhu, X., Zhu, L., Chen, Y. \& Tian, S. (2009). Acute toxicities of six manufactured nanomaterial suspensions to Daphnia magna. Journal of Nanoparticle Research, 11(1), 67-75. 